\title{
FAKTOR- FAKTOR YANG MENYEBABKAN STATUS GIZI KURANG PADA BALITA DI WILAYAH KERJA PUSKESMAS SAIL PEKANBARU TAHUN 2016
}

\author{
Berliana Irianti \\ Kebidanan, Akademi Kebidanan Internasional Pekanbaru, berlianairianti@yahoo.com
}

\section{INFO ARTIKEL}

Riwayat Artikel:

Diterima: 17-05-2018

Disetujui: 10-06-2018

\section{Kata Kunci: \\ Status Gizi Kurang \\ Pengetahuan \\ Sosial ekonomi \\ Jarak kelahiran}

\begin{abstract}
ABSTRAK
Abstrak: : Status gizi merupakan keadaan kesehatan tubuh seseorang atau sekelompok orang yang diakibatkan oleh konsumsi, penyerapan serta penggunaan zat gizi. Faktor yang menyebabkan terjadinya status gizi kurang pada anak balita: Jarak kelahiran yang terlalu rapat, sosial ekonomi, ketidaktahuan akan hubungan makanan dan kesehatan, prasangka buruk terhadap bahan makanan tertentu, kesukaan yang berlebihan terhadap jenis makanan tertentu, penyakit infeksi. Adapun tujuan penelitian ini untuk mengetahui faktorfaktor yang menyebabkan status gizi kurang pada balita di wilayah kerja puskesmas Sail tahun 2016. Jenis penelitian kuantitatif dan desain penelitian deskriptif. Lokasi penelitian dilaksanakan di wilayah kerja puskesmas Sail dan waktu penelitian dilaksanakan pada tanggal 15-20 Februari 2016. Populasinya ibu yang memiliki balita dengan status gizi kurang di wilayah kerja Puskesmas Sail berjumlah 20 kasus dan sampel berjumlah 20 kasus balita gizi kurang. Instrumen penelitian menggunakan lembar check list dan teknik pengumpulan data menggunakan data primer. Hasil penelitian didapatkan bahwa dari 20 responden mayoritas faktor pengetahuan ibu yang memiliki balita dengan status gizi kurang adalah rendah sebanyak 11 orang $(55 \%)$, dan mayoritas faktor tingkat ekonomi orang tua adalah Rendah sebanyak 12 orang $(60 \%)$ dan mayoritas faktor jarak kelahiran yang terlalu rapat sebanyak 12 orang (60\%). Kesimpulan: faktor-faktor yang menyebabkan status gizi kurang pada balita yaitu faktor tingkat ekonomi orang tua dan jarak keahiran. Dari hasil penelitian ini peneliti berharap bisa menjadi bahan masukan instansi kesehatan dengan meningkatkan pengetahuan ibu tentang status gizi kurang pada balita melalui penyuluhan dari petugas kesehatan dan memberikan makanan tambahan bagi balita tersebut
\end{abstract}

\begin{abstract}
Nutrition status is a health condition of a person's body or a group of people caused by consumption, absorption and the use of nutrients. Factors leading to undernourishment in under-five children: Overcrowded birth, socioeconomic, ignorance of food and health relationships, prejudice against certain food items, overabundance of certain types of food, infectious diseases. The purpose of this study to determine the factors that cause underweight nutritional status in infants in the working area of sail health center in 2016. Quantitative research type and descriptive research design. The location of the research was conducted in the working area of Sail Health Centre and the time of the research on February 15-20, 2016. The population of mothers who had under-five children with less nutritional status in Sail Health Centre were 20 cases and all were used as research samples. The research instrument uses check list and data collection techniques using primary data. The result showed that from 20 respondents, the majority of knowledge factors of mothers who have under five children with low nutritional status are low knowledge as many as 11 people (55\%), and the majority of factors of economic level of parents are low as many as 12 people (60\%) and majority of birth distance factor which is too tight as many as 12 people (60\%). Conclusion: the factors that cause poor nutritional status in children under five are factors of parents' economic level and distance of expertise. From the results of this study, the researcher hopes to become input material of health institution by improving mother's knowledge about nutrient status less on toddler through counseling from health officer and providing supplementary food for the toddler
\end{abstract}

\section{A. LATAR BELAKANG}

Status gizi adalah keadaan tubuh sebagai akibat konsumsi makanan dan penggunaan zat-zat gizi. Status gizi ini menjadi penting karena merupakan salah satu faktor risiko untuk terjadinya kesakitan dan kematian. Status gizi yang baik bagi seseorang akan berkontribusi terhadap kesehatannya dan juga terhadap kemampuan dalam proses pemulihan. Status gizi masyarakat dapat diketahui melalui penilaian konsumsi pangannya berdasarkan data kuantitatif maupun kualitatif. Di negara berkembang, kesakitan dan kematian pada anak balita banyak dipengaruhi oleh status gizi (Supariasa, 2001). Status gizi balita perlu dipertahankan dalam status gizi baik, dengan cara memberikan makanan bergizi seimbang yang sangat penting untuk pertumbuhan (Paath, 2004).

Keadaan gizi yang baik merupakan salah satu faktor penting dalam upaya mencapai derajat kesehatan yang optimal. Namun, berbagai penyakit gangguan gizi dan gizi buruk akibat tidak baiknya mutu makanan maupun jumlah 
makanan yang tidak sesuai dengan kebutuhan tubuh masing-masing orang masih sering ditemukan diberbagai tempat di Indonesia. Rendahnya status gizi jelas berdampak pada kualitas sumber daya manusia. Masalah gizi di Indonesia yang terbanyak adalah gizi kurang. Anak balita (0-5 tahun) merupakan kelompok umur yang paling sering menderita akibat kekurangan gizi atau termasuk salah satu kelompok masyarakat yang rentan gizi.

Berdasarkan data UNICEF menunjukkan pada tahun 2012 diperkirakan 25\% atau 162 juta anak-anak diseluruh dunia mengalami malnutrisi, sedangkan di Indonesia terdapat $36 \%$ balita yang mengalami malnutrisi. Gizi kurang merupakan salah satu masalah gizi utama pada balita di Indonesia. Prevalensi gizi kurang dan gizi buruk mulai meningkat pada usia 6-11 bulan dan mencapai puncaknya pada usia 12-23 bulan dan 24-35 bulan (UNICEF, 2012)

Status gizi dipengaruhi oleh 2 faktor, yaitu langsung dan tidak langsung. Faktor langsung yaitu penyakit infeksi, jenis pangan yang yang dikonsumsi baik secara kualitas maupun kuantitas. Faktor tidak langsung antara lain: sosial ekonomi, Jarak kelahiran yang terlalu rapat, pendidikan, pengetahuan, ketidaktahuan akan hubungan makanan dan kesehatan, prasangka buruk terhadap bahan makanan tertentu, kesukaan yang berlebihan terhadap jenis makanan tertentu, pendapatan, pola asuh yang kurang memadai, sanitasi lingkungan yang kurang baik, rendahnya ketahanan pangan tingkat rumah tangga dan perilaku terhadap pelayanan kesehatan.

Berdasarkan latar belakang diatas, peneliti tertarik melakukan penelitian dengan judul faktor- faktor yang menyebabkan status gizi kurang pada balita di wilayah kerja puskesmas sail pekanbaru tahun 2016

\section{B. METODE PENELITIAN}

Penelitian ini merupakan penelitian yang jenisnya kuantitatif dengan desain deskriptif yaitu suatu metode penelitian yang dilakukan dengan tujuan utama untuk membuat gambaran, bagaimana faktor - faktor yang menyebabkan status gizi kurang pada balita di wilayah kerja Puskesmas Sail.

Data yang diperoleh akan dianalisa secara bertahap yaitu analisis univariat. untuk melihat bagaimana faktor-faktor yang menyebabkan status gizi kurang pada balita penelitian ini menggunakan kuisioner dan lembar ceklis yang telah tervalidasi yang berisi sejumlah pertanyaan yang berhubungan dengan masalah yang diteliti yaitu pernyataan mengenai faktor pengetahuan ibu yang memiliki balita mengenai status gizi kurang pada balita yang disusun oleh peneliti sendiri berdasarkan tinjauan teoritis yang ada

Tempat penelitian akan dilakukan di Wilayah kerja Puskesmas Sail. Waktu penelitian dilaksanakan pada tanggal 15-20 Februari 2016. Populasi dalam penelitian adalah seluruh ibu yang memiliki balita dengan status gizi kurang sebanyak 20 orang. Pengambilan sampel menggunakan sampel jenuh, seluruh populasi dijadikan sampel penelitian. Analisis ini dilakukan untuk melihat distribusi frekuensi dan persentase dari tiap-tiap variable. Disajikan dalam bentuk tabel distribusi frekuensi guna mendapatkan gambaran umum. Tujuan analisis ini adalah untuk menjelaskan atau mendiskripsikan faktor dangan menggunakan rumus :

$$
p=\frac{F}{N} X 100 \%
$$

\section{HASIL DAN PEMBAHASAN}

\section{Hasil}

a. Pengetahuan Responden

Tabel 1

Distribusi Frekuensi Pengetahuan Responden

\begin{tabular}{cccc}
\hline No & Pengetahuan & Frekuensi & Persentase \\
\hline 1 & Tinggi & 9 & $45 \%$ \\
2 & Rendah & 11 & $55 \%$ \\
\hline & Jumlah & 20 & $100 \%$ \\
\hline
\end{tabular}

b. Perekonomian Responden

Tabel 2

Distribusi Frekuensi Berdasarkan Perekonomian Responden

\begin{tabular}{cccc}
\hline No & Perekonomian & Frekuensi & Persentase \\
\hline 1 & Tinggi & 8 & $40 \%$ \\
2 & Rendah & 12 & $60 \%$ \\
\hline & Jumlah & 20 & 100 \\
\hline
\end{tabular}

c. Jarak Kelahiran

Tabel 3

Distribusi Frekuensi Jarak Kelahiran Yang Terlalu Rapat

\begin{tabular}{cccc}
\hline No & $\begin{array}{c}\text { Jarak } \\
\text { Kelahiran }\end{array}$ & Frekuensi & Persentase \\
\hline 1 & Ya & 12 & 60 \\
2 & Tidak & 8 & 40 \\
\hline & Jumlah & 20 & 100 \\
\hline
\end{tabular}

\section{Pembahasan}

\section{a. Pengetahuan}

Dari hasil penelitian yang telah dilakukan pengetahuan ibu balita dengan balita status gizi kurang adalah Rendah yaitu 11 (55\%) Tinggi yaitu 9 orang (45\%). Dari data tersebut dapat diketahui bahwa mayoritas pengetahuan ibu yang memiliki balita status gizi kurang diwilayah kerja puskesmas Sail adalah Rendah.

Pengetahuan merupakan hasil tahu dan ini terjadi setelah orang melakukan pengindraan terhadap objek tertentu. Pengindraan terjadi melalui panca indra manusia, yakni indra penglihatan, penciuman, rasa dan raba. Sebagian besar pengetahuan manusia diperoleh melalui mata dan telinga. Pengetahuan domain yang sangat penting dalam membentuk tindakan seseorang. Berarti tinggi rendahnya pengetahuan 
seseorang dipengaruhi oleh cukup tidaknya informasi dan pengetahuan orang lain, dan pengalaman yang didapat.

Penelitian ini sejalan dengan peneliti Ariyani (2011) dimana hasil penelitian di dapatkan sebagian Tingkat pendidikan yang rendah ini mempengaruhi tingkat pengetahuan dan penghasilan orang tua balita.

Menurut peneliti, pengetahuan ibu sangat signifikan sekali pada pertumbuhan balita. Pengetahuan ibu yang rendah mengakibatkan pertumbuhan balita tidak baik dan mengakibatkan kekurangan gizi. Ibu kurang mendapatkan informasi mengenai bagaimana cara memilih bahan makanan yang tepat untuk balita, bagaimana memasak yang baik dan benar, serta bagaimana cara memilih menu makanan yang baik untuk keluarga. Untuk iiknyatu ibu sebaiknya mencari informasi baik dari buku ataupun tenaga kesehatan.

b. Perekonomian

Dari hasil penelitian yang telah dilakukan perekonomian orang tua balita menderita status gizi kurang adalah Rendah 12 orang (60\%), Tinggi yaitu 8 orang (40\%),

Menurut Notoadmodjo (2005) status ekonomi adalah suatu konsep untuk mengukur konsep ekonomi, dapat melalui variabel pendapatan atau pengeluaran keluarga. Ada dua stratifikasi dalam penelitian ekonomi suatu daerah. Stratifikasi yang menggambarkan keadaan sosial ekonomi masyarakat yang digunakan dalam menentukan tingkat kemiskian penduduk dan stratifikasi yang digunakan untuk menilai setiap individu. Menurut guru besar Ekonomi Kesehatan, Ascobat Gani, persoalan pokok terjadinya balita gizi kurang di Indonesia karena kegagalan negara untuk mengatasi kemiskinan.

Penelitian ini sejalan dengan penelitian Novitasari (2012) diperoleh hasil bahwa terdapat hubungan yang bermakna antara status sosial ekonomi dengan kejadian gizi kurang. Selain itu diperoleh pula status sosial ekonomi merupakan faktor resiko terjadinya resiko status gizi kurang. Menurut Almaghribi (2013) masalah gizi terjadi karena kemiskinan, indikatornya adalah taraf ekonomi keluarga, yang hubungannya dengan daya beli yang dimiliki keluarga tersebut.

Dari hasil penelitian, perekonomian orang tua yang rendah salah satu yang menyebabkan terjadinya gizi kurang pada balita. Ibu dengan perekonomian keluarganya yang rendah tetap dapat memberikan makanan yang bergizi seperti tempe, tahu, dan telur sebagai pengganti ikat dan daging. Karena kadar gizi didalamnya sama. Oleh karena itu tidak hanya makanan yang mahal yang memiliki gizi yang baik, menjaga pola hidup sehat juga dapat meningkat kesehatan keluarga.

\section{c. Jarak Kelahiran}

Dari hasil penelitian yang telah dilakukan dari faktor jarak kelahiran yang terlalu rapat akan mempengaruhi makanan yang dikonsumsi oleh seorang anak didapat usia $<2$ tahun sebanyak 12 orang (60\%) dan $\geq 2$ th sebanyak 8 orang (40\%).

Menurut Marimbi (2010) yang membuktikan bahwa banyak anak yang menderita gangguan gizi oleh karena ibunya sedang hamil lagi atau adiknya yang baru telah lahir, sehingga ibunya tidak dapat merawatnya secara baik. Anak yang dibawah usia 2 tahun masih sangat memerlukan perawatan ibunya, baik perawatan makanan maupun perawatan kesehatan dan kasih sayang, jika dalam masa 2 tahun itu ibu sudah hamil lagi,maka bukan saja perhatian ibu terhadap anak akan menjadi berkurang akan tetapi air susu ibu (ASI) yang masih sangat dibutuhkan anak akan berhenti keluar.

Anak yang belum dipersiapkan secara baik untuk menerima makanan pendamping ASI, yang kadang- kadang mutu gizi makanan tersebut juga sangat rendah, dengan penghentian pemberi ASI karena produksi ASI berhenti, akan lebih cepat mendorong anak menderita gizi buruk, yang apabila tidak segera diperbaiki maka akan menyebabkan kematian. Karena alasan inilah dalam usaha meningkatkan kesejahteraan keluarga,disamping memperbaiki gizi juga perlu dilakukan usaha untuk mengatur jarak kelahiran (Marimbi, 2010).

Menurut peneliti, penelitian tersebut dapat diketahui memang jarak kelahiran yang yang terlalu rapat dapat menyebabkan terjadinya gizi kurang pada balita. Untuk tidak terjadinya balita gizi kurang maka orang tua haruslah mengatur jarak kelahiran anaknya. Agar mereka bisa menghidupi keluarganya dengan baik khususnya dapat memberikan gizi yang terbaik buat balitanya.

\section{SIMPULAN DAN SARAN}

Pengetahuan ibu yang memiliki balita menderita status gizi kurang di wilayah kerja Puskesmas Sail adalah rendah 11 orang (55\%). Perekonomian ibu yang memiliki balita menderita status gizi kurang di wilayah kerja Puskesmas Sail adalah rendah yaitu 12 orang (60\%). Jarak Kelahiran anak yang terlalu dekat di wilayah kerja puskesmas sail adalah Ya ( $<2$ th ) yaitu 12 orang (60\%).

Bagi pihak puskesmas meningkatkan kualitas tentang status gizi kurang dan frekuensi dalam memberikan 
penyuluhan tentang status gizi kurang yaitu cara Preventif, Promotif, Rehabilitatif, kuratif, dan pemberian makanan tambahan. Juga dapat memberikan penyuluhan tentang cara memilih, mengolah,dan menyajikan masakan yang benar sesuai dengan tingkat ekonomi ibu.

\section{UCAPAN TERIMA KASIH}

Kepada Kepala Puskesmas Sail Pekanbaru beserta Staf sebagai tempat penelitian, Direktur dan Ketua LPPM yang telah mengizinkan untuk melakukan penelitian.

\section{DAFTAR RUJUKAN}

[1] Almatsier, S (2001). Prinsip Dasar IImu Gizi. Jakarta : Gramedia Pustaka Utama

[2] Badriah, (2011). Gizi dalam Kesehatan Reproduksi. Bandung : PT. Refika Aditama.

[3] Bungin, (2005). Metodelogi Penelitian Kuantitatif. Jakarta : kencana.

[4] Hasil Riset Kesehatan Dasar (Riskesdas), (2013). Balita Gizi Buruk dan Kurang. http://www.kompasiana.com/debe/4-6-juta-balita-gizi-buruk-kurang-di-indonesiapertanda-ketahanan-pangan-lampukuningkah 54f4bf79745513982b6c8ecf ( 18 januari 2016)

[5] Hidayat, AA (2007). Metode Penelitian Kebidanan dan Teknik Analisis Data. Surabaya : Salemba Medika.

[6] Istiany, (2013). Gizi Terapan. Bandung : PT. Remaja Rosdakarya.

[7] Marimbi, (2010). Tumbuh Kembang, Status Gizi, dan Imunisasi Dasar pada Balita. Yogyakarta : Nuha Medika.

[8] Notoatmojo, (2002). Metodologi Penelitian Kesehatan. Jakarta : PT. Rineka Cipta.

[9] Paath,E.F. (2004).Gizi dalam Kesehatan Reproduksi. Jakarta : EGC.

[10] Proverawati Atikah, Wati Kusuma. (2011). IImu Gizi Untuk Gizi Keperawatan \& Gizi Kesehatan. Yogyakarta : Nuha Medika

[11] Suharjo. (2003). Status Gizi. Jakarta: Nuha Medika.

[12] Supariasa I, dkk. (2001). Penilaian Status Gizi. Jakarta : Buku Kedokteran EGC.

\section{PROFIL PENULIS UTAMA}

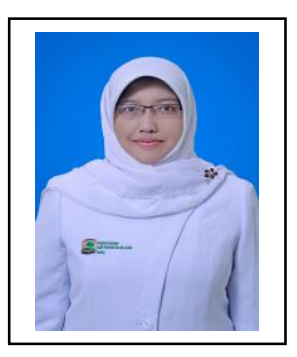

Berliana Irianti, dilahirkan di Pekanbaru pada tahun 1982. Penulis menyelesaikan pendidikan D-III Kebidanan di Poltekkes Depkes Riau tahun 2004, Program D IV Bidan Pendidik di Poltekkes Kemenkes Padang Tahun 2007 dan memperoleh gelar Master Kebidanan dari Universitas Andalas Padang pada tahun 2015. Dari tahun 2008 hingga sekarang, penulis bekerja sebagai Dosen D III Kebidanan di Akademi Kebidanan Internasional Pekanbaru, Riau. Penulis aktif dalam melakukan penelitian dan penyusunan karya ilmiah di lingkungan Akademi Kebidanan dan Kopertis wilayah X 